\title{
Poliosis and Neurofibromatosis Type 1: Two Familiar Cases and Review of the Literature
}

\author{
Iria Neri Giulia Liberati Bianca Maria Piraccini Annalisa Patrizi \\ Dermatology, Department of Experimental, Diagnostic and Specialty Medicine, S. Orsola-Malpighi Hospital, \\ University of Bologna, Bologna, Italy
}

\section{Established Facts}

- Poliosis on the scalp in neurofibromatosis type 1 is rare.

\section{Novel Insights}

- We report two familiar cases of poliosis overlying plexiform neurofibromas in the same location in patients with neurofibromatosis type 1 .

\section{Keywords}

Poliosis · Neurofibromatosis type 1 - Plexiform neurofibromas $\cdot$ Scalp

\begin{abstract}
Two brothers were referred to our clinic for reevaluation of neurofibromatosis type 1 (NF1). Both brothers presented a peculiarity that is not so common in NF1: poliosis overlying plexiform neurofibromas on the scalp. Poliosis overlying plexiform neurofibromas is rarely reported in the literature. The peculiarity of our cases is the familiarity and the presence of poliosis in the same location.
\end{abstract}

(C) 2017 S. Karger AG, Basel
(C) 2017 S. Karger AG, Basel

\section{KARGER}

E-Mail karger@karger.com

www.karger.com/sad

\section{Brief Report}

Two brothers presented at our clinic for reevaluation of neurofibromatosis type 1 (NF1), which had been diagnosed, respectively, at 1 and 6 years. The oldest was 40 years old (case 1 ) and the other 34 years old (case 2). Family history revealed that their father, their paternal uncle, and their paternal grandmother had NF1, but there was no history of poliosis or achromic macules. We report the clinical cutaneous findings of the two brothers and the findings of other cases described in the literature in Table 1. Systemic symptoms of our cases are reported in Table 2.

Both brothers presented a peculiarity that is not so common in NF1: poliosis overlying plexiform neurofibromas on the scalp (Fig. 1). Neurofibromas are benign proliferations of the neural element of the peripheral nerve; they can develop from the Schwann cells or fibroblasts. Single or multiple skin neurofibromas are observed in more than $95 \%$ of cases of NF1. Plexiform neurofibromas, occurring in $30 \%$ of cases, are multiple neurofibromas with diffuse neural expansion along the peripheral nerve [1].

Giulia Liberati

Department of Experimental, Diagnostic and Specialty Medicine S. Orsola-Malpighi Hospital, University of Bologna

Via Massarenti 1, IT-40138 Bologna (Italy)

E-Mail giulia.liberati83@gmail.com 
Table 1. Features of the patients with poliosis and neurofibromas

\begin{tabular}{|c|c|c|c|c|c|}
\hline & Case 1 & Case 2 & Case 3 & Case 4 & Case 5 \\
\hline Sex & Man & Man & Man & Woman & Man \\
\hline $\begin{array}{l}\text { Age of the patient } \\
\text { at dermatological } \\
\text { visit, years }\end{array}$ & 40 & 34 & 19 & 32 & 38 \\
\hline Site of poliosis & $\begin{array}{l}\text { Right parieto-occipital } \\
\text { region }\end{array}$ & $\begin{array}{l}\text { Right temporo-parietal } \\
\text { region }\end{array}$ & $\begin{array}{l}\text { Left temporo-parietal } \\
\text { region }\end{array}$ & Left temporal region & $\begin{array}{l}\text { Right parieto-occipital } \\
\text { region }\end{array}$ \\
\hline $\begin{array}{l}\text { Site of scalp } \\
\text { neurofibroma }\end{array}$ & $\begin{array}{l}\text { Right parieto-occipital } \\
\text { region }\end{array}$ & $\begin{array}{l}\text { Right temporo-parietal } \\
\text { region }\end{array}$ & $\begin{array}{l}\text { Left temporo-parietal } \\
\text { region }\end{array}$ & Left temporal region & $\begin{array}{l}\text { Right parieto-occipital } \\
\text { region }\end{array}$ \\
\hline $\begin{array}{l}\text { Plexiform } \\
\text { neurofibroma } \\
\text { of the scalp }\end{array}$ & Yes & Yes & No & No & Yes \\
\hline $\begin{array}{l}\text { Clinical features } \\
\text { of neurofibro- } \\
\text { matosis }\end{array}$ & $\begin{array}{l}\text { Multiple nodular } \\
\text { neurofibromas on the } \\
\text { trunk, arms, and legs, } \\
\text { plexiform } \\
\text { neurofibromas in the } \\
\text { pubic region and plantar } \\
\text { region, blue-red pseudo- } \\
\text { atrophic macules on the } \\
\text { trunk, freckles in the } \\
\text { axillary regions, café au } \\
\text { lait spots, piezogenic } \\
\text { papules on the feet }\end{array}$ & $\begin{array}{l}\text { Multiple nodular } \\
\text { neurofibromas, multiple } \\
\text { plexiform } \\
\text { neurofibromas, one of } \\
2 \mathrm{~cm} \text { in diameter on the } \\
\text { right parietal region, } \\
\text { another on the dorsal } \\
\text { region }\end{array}$ & $\begin{array}{l}\text { Isolated neurofibroma; } \\
\text { no familiar history of } \\
\text { neurofibromatosis type } \\
1\end{array}$ & $\begin{array}{l}\text { Isolated neurofibroma; } \\
\text { no familiar history of } \\
\text { neurofibromatosis }\end{array}$ & $\begin{array}{l}\text { Axillary freckling, } \\
\text { multiple café au lait } \\
\text { macules plus dome- } \\
\text { shaped, soft, multiple } \\
\text { superficial neuro- } \\
\text { fibromas, trunk and } \\
\text { extremities; no eye } \\
\text { abnormality; normal } \\
\text { physical and mental } \\
\text { development; maternal } \\
\text { aunt had piebaldism; a } \\
\text { son with neuro- } \\
\text { fibromatosis type } 1\end{array}$ \\
\hline $\begin{array}{l}\text { Age of onset of } \\
\text { neurofibroma }\end{array}$ & First years of life & First years of life & 4 years & 22 years & Not indicated \\
\hline $\begin{array}{l}\text { Age of onset of } \\
\text { poliosis }\end{array}$ & First years of life & First years of life & 12 years & $\begin{array}{l}\text { Six months after the } \\
\text { neurofibroma began to } \\
\text { grow }\end{array}$ & 23 years \\
\hline References & Patient we visited & Patient we visited & $\begin{array}{l}\text { Patient described } \\
\text { by Koplon and Shapiro } \\
{[5]}\end{array}$ & $\begin{array}{l}\text { Patient described by } \\
\text { Kwon et al. [3] }\end{array}$ & $\begin{array}{l}\text { Patient described by } \\
\text { Sandoval-Tress and } \\
\text { Nava-Jiménez [4] }\end{array}$ \\
\hline
\end{tabular}

Table 2. Systemic symptoms of the two brothers

\begin{tabular}{ll}
\hline Case 1 & Case 2
\end{tabular}

Hypophosphatemic rickets

Empty sella syndrome

Hyperlipidemia

Fatty liver disease

Depression

Panic attacks

Bilateral sensorineural hearing loss

Osteochondritis dissecans of the medial femoral

condyle of the left knee

Hypertension

Prostatic hypertrophy

Irises with Lisch nodules
Aortic coarctation surgically corrected at the age of 12 Incomplete right bundle branch block

Three neurofibromas in the heart

No ophthalmological abnormality 

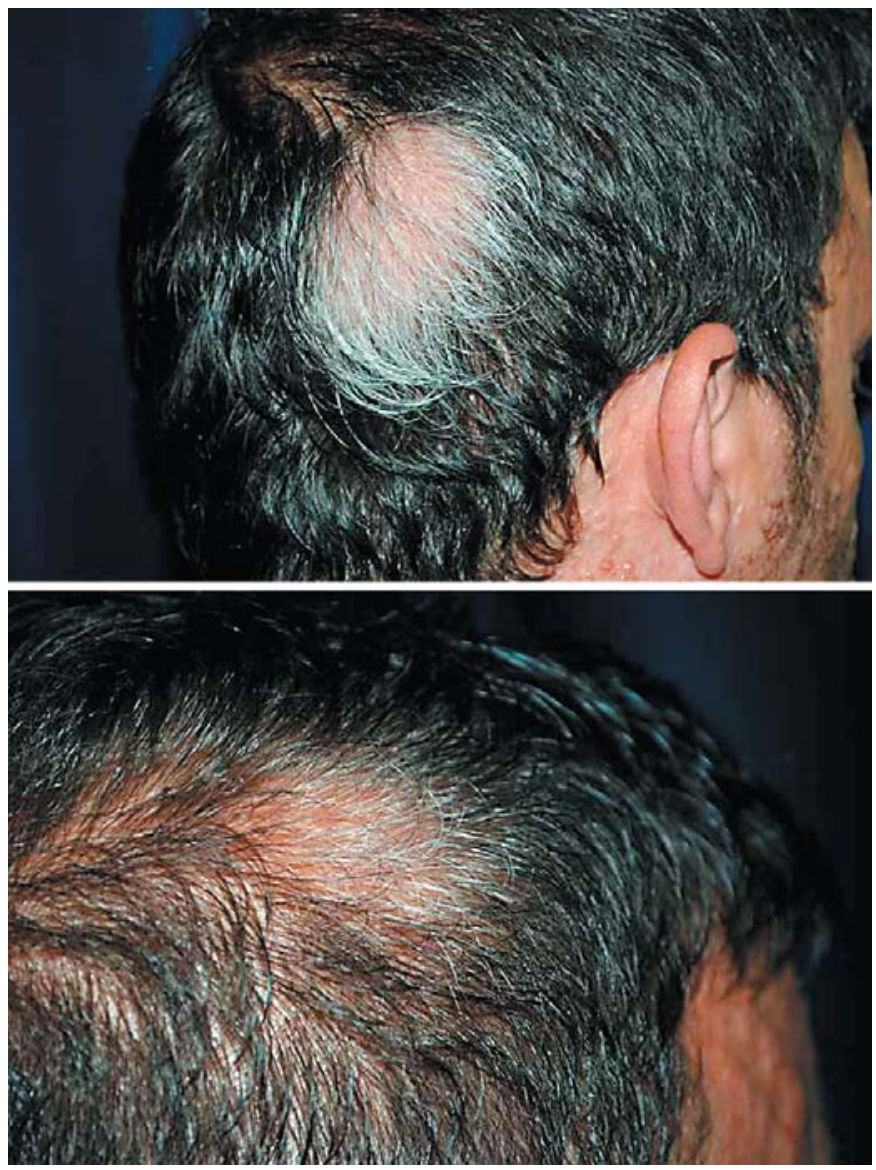

Fig. 1. Case 1 and case 2 .

Poliosis circumscripta is a localized patch of white hair in a group of hair follicles, known as "white forelock," secondary to the involvement of the central frontal scalp, but it can involve any hairy area of the body, including the eyebrows, eyelashes, and beard [2]. Microscopically, poliosis demonstrates either decreased or absent melanin and/or melanocytes in the hair bulbs of the affected hair follicles [2]. The epidermal melanocytes are usually not affected, unless there is associated vitiligo [2].

In children, poliosis may be the presenting sign of several hereditary syndromes that should alert the physician to look for other cutaneous manifestations [2]. In fact it may occur in several genetic syndromes including piebaldism, Waardenburg syndrome, and tuberous sclerosis [2].

Poliosis overlying plexiform neurofibromas is rarely reported in the literature. To our knowledge, only three cases have been described, in two of which the neurofibromas are isolated, while in the third case, the patient was affected by NF1 [2-5]. In our two familiar cases, the patients had NF1 onset in the first years of life.

In our cases and in all the cases described in the literature, the neurofibromas were localized on the scalp, in the lateral-temporoparietal region; they were acquired in all cases, including our own, except for one case, in which it is not indicated. It has been hypothesized that in such cases, poliosis is probably due to an autoimmune response in which the $\mathrm{T}$ cells cytotoxic to neurofibroma might cross-react with surrounding hair bulb melanocytes, resulting in the their destruction with subsequent whitish discoloration of the hair surrounding the neurofibroma [2].

The peculiarity of our cases is the familiarity and the presence of poliosis in the same location. More studies are needed to explain the exact relation between poliosis and neurofibromas.

\section{Statement of Ethics}

All authors confirm that all the research meets the ethical guidelines, including adherence to the legal requirements of the study country. Patient consent has been obtained.

\section{Disclosure Statement}

All authors have not conflict of interest.

\section{References}

Poliosis and Neurofibromatosis Type 1
1 Sarica FB, Cekinmez M, Tufan K, Erdoğan B, Sen O, Altinörs MN: A rare case of massive NF1 with invasion of entire spinal axis by neurofibromas: case report. Turk Neurosurg 2008;18:99-106.

2 Sleiman R, Kurban M, Succaria F, Abbas O: Poliosis circumscripta: overview and underlying causes. J Am Acad Dermatol 2013;69: 625-633.
3 Kwon IH, Cho YJ, Lee SH, Lee JH, Cho KH, Kim JA, Moon SE: Poliosis circumscripta associated with neurofibroma. J Dermatol 2005; 32:446-449.

4 Sandoval-Tress C, Nava-Jiménez G: Poliosis circumscripta associated with neurofibromatosis 1. Australas J Dermatol 2008;49:167168.

5 Koplon BS, Shapiro L: Poliosis overlying a neurofibroma. Arch Dermatol 1968;98:631633. 